\title{
The use of a one-step PCR method for the identification of Microsporum canis and Trichophyton mentagrophytes infection of pets
}

\author{
Iwona Dąbrowska1 ${ }^{\llbracket}$, Bożena Dworecka-Kaszak and Anna Brillowska-Dąbrowska² \\ 'Division of Microbiology, Department of Preclinical Sciences, Faculty of Veterinary Medicine, Warsaw University of Life Sciences-SGGW, War- \\ szawa, Poland; ${ }^{2}$ Gdansk University of Technology, Department of Microbiology, Gdańsk, Poland
}

\begin{abstract}
Introduction: Dermatophytes are a closely related group of keratinophilic fungi. They encompass important etiological agents of superficial fungal infections. These fungi are able to invade keratinized tissues of humans and animals, causing dermatophytosis (ringworm) of hair, nails or skin. The aim: Traditional diagnostics of ringworm is based on morphological identification of cultured fungi and is time-consuming. Materials and methods: In this study, we applied a method patented by Brillowska-Dabrowska and coworkers (BrillowskaDąbrowska A, Saunte DM, Arenderup MC, 2007, Fivehour diagnosis of dermatophyte nail infections with specific detection of Trichophyton rubrum. J Clin Microbiol 45: 1200-1204) which involves extraction of fungal DNA and PCR amplification with pan-dermatophyte primers to confirm the presence of dermatophytes. Results: The method used here is able to confirm the presence of dermatophyte DNA in pure cultures in less than 5 hours.
\end{abstract}

Key words: dermatophytosis, animals, pan-dermatophytes, PCR,

Received: 12 February, 2014; revised: 02 April, 2014; accepted: 28 April, 2014; available on-line: 18 June, 2014

\section{INTRODUCTION}

Dermatophytes and yeasts are the major etiological factors of superficial fungal infections. They are common worldwide and their incidence continues to increase (Ameen, 2010). Superficial infections or colonization of keratinized tissue caused by dermatophytes - dermatophytoses, (ringworm or tinea) occur in both healthy and immunocompromised patients (Jaya et al, 2009). These cosmopolitan mycoses afflict an extensive range of mammals, including humans, but rarely concern birds. Pets are often infected as well as livestock. Because of the contagiousness, difficulties in identification and costly treatment there is a high occurrence of dermatophytoses, especially in animal herds. Animal ringworm can be easily transmitted to humans (Chermette et al., 2008). The main lesions of dermatophytoses are alopecia, erythema, papules, scaling or crusting. The classic clinical changes are well separated, with active inflammation at the periphery - hence ringworm.

Dermatophytes are keratinophilic pathogenic fungi that utilise keratin as a nutrient source. These fungi invade the stratum corneum of the epidermis and keratinized tissues derived from it (e.g., skin, hair, nails, fur)
(Chermette et al., 2008; Putignani et al., 2010). Taxonomically, these filamentous fungal pathogens belong to three related anamorphic (imperfect or asexual) genera: Microsporum, Trichophyton, and Epidermophyton (pathogenic for humans only). Individual species capable of reproducing sexually are classified in the teleomorphic genus Arthroderma of the Ascomycota. (Weitzman \& Summerbell, 1995).

Animals can be infected by a variety of dermatophytes. These include zoophilic, geophilic (soil-adapted) as well as anthropophilic (adapted to human hosts) species. The most frequently isolated dermatophyte species from animals are: Microsporum canis, Microsporum gypseum, Microsporum nanum, Trichophyton mentagrophytes, Trichophyton verrucosum and Trichophyton equinum (Weitzman \& Summerbell, 1995; Chermette et al., 2008).

Routine, conventional laboratory diagnostics of dermatophytoses ("the gold standard") involve direct microscopic examination of clinical specimens followed by in vitro culture techniques (Liu et al., 2000; Mahoney et. al., 2003). Microscopic identification of fungal elements directly in clinical samples using potassium hydroxide $10 \%(\mathrm{KOH})$ is a quick method, but its specificity and sensitivity is low and proper execution depends on the researchers' experience. Moreover, false negative results are possible. According to Levitt and coworkers (2010) the sensitivities for $\mathrm{KOH}$ smear and culture were $73.3 \%$ (CI: 66.3 to $79.5 \%$ ) and $41.7 \%$ (34.6 to $49.1 \%$ ) respectively. Although somewhat specific, in vitro culture as a diagnostic procedure is time-consuming. (Jaya et al., 2009). It might take up to 4 weeks or longer to give the final results or are not succesfull. Furthermore, morphological identification may be confusing due to polymorphism of dermatophytes (Putignani et al., 2010).

Polymerase chain reaction (PCR)-based techniques shorten the diagnostic procedure and generally have high sensitivity and specificity compared to conventional methods (Jaya et al., 2009, Dworecka-Kaszak, 2011). Many PCR-based techniques such as PCR fingerprinting (Graser et al., 2000; Faggi et al., 2002), Random Amplification of Polymorphic DNA (RAPD) (Hryncewicz et al., 2011), Restriction Fragment Length Polymorphism (RFLP) (Arabatzis et al. 2006) and real-time PCR (Wisselink et al., 2011) have been used recently to identify dermatophytes from in vitro cultures.

Further, TRFLP (PCR-terminal restriction fragment length polymorphism) (Verrier et al., 2012), nested PCR (Verrier et al., 2013) or PCR-ELISA (Tchernev et al.,

e-mail: iwona_dabrowska@sggw.pl

Abbreviations: $\bar{P} C R$, polymerase chain reaction 
2013) have also found there use in identification of previously cultured dermatophytes. However, there is still need to design a rapid, reliable and reproducible molecular-based protocol that can be easily implemented in diagnostic laboratories to handle large volumes of clinical specimens in a reasonable time. The main problem, however, is the lack of a reliable procedure to extract intact fungal DNA directly from clinical specimens.

The aim of this work was to apply PCR to detect veterinary ringworm-causing species based on a technique described earlier by Brillowska-Dabrowska and coworkers (2007) for identification of human onychomycosis. It involves a fungal DNA extraction step followed by pan-dermatophyte PCR and electrophoresis. Our results confirm the presence of dermatophyte-specific DNA in specimens derived from cultured clinical samples. Adaptation of this procedure indicates a possibility of designing a reliable protocol for quick detection of dermatophytes-specific DNA directly in veterinary clinical samples.

\section{MATERIALS AND METHODS}

Clinical isolates. Clinical specimens were obtained from the microbiology diagnostic laboratory at the Faculty of Veterinary Medicine, Warsaw University of Life Sciences-SGGW (Warsaw, Poland). Fifteen hair samples from 8 cats and 7 dogs (Fig. 1) suspected of ringworm were initially examined by direct microscopy and cultured on Sabouraud dextrose agar (SDA). Ringworm was identified in all specimens. Culture conditions were as follows: Sabouraud dextrose agar supplemented with chloramphenicol $(0.05 \mathrm{~g} / \mathrm{l})$ and cycloheximide $(0.4 \mathrm{~g} / \mathrm{l})$, at $30^{\circ} \mathrm{C}$ for up to 14 days. Pure cultures were derived basing on macro- and micromorphology (Fig. 2A and B).

DNA preparation from dermatophyte cultures. The method proposed by Brillowska-Dabrowska and coworkers (2007) was used to isolate DNA from dermatophytes: Briefly, fungal colonies were picked and incubated for 10-min in $100 \mu$ l of extraction buffer A $(60$ $\mathrm{mM}$ sodium bicarbonate $\left(\mathrm{NaHCO}_{3}\right), 250 \mathrm{mM}$ potassium chloride $(\mathrm{KCl})]$ and $50 \mathrm{mM}$ Tris, $\mathrm{pH} 9.5)$ at $95^{\circ} \mathrm{C}$. Subsequently, a $100 \mu \mathrm{l}$ of $2 \%$ bovine serum albumin, (BSA) was added and mixed thoroughly. The DNA-containing solution was used for PCR assay.

Pan-dermatophyte PCR. A set of primers detecting a DNA fragment encoding chitin synthase1 of dermatophytes, panDerm_for (5'GAAGAAGATTGTCGTT'T-

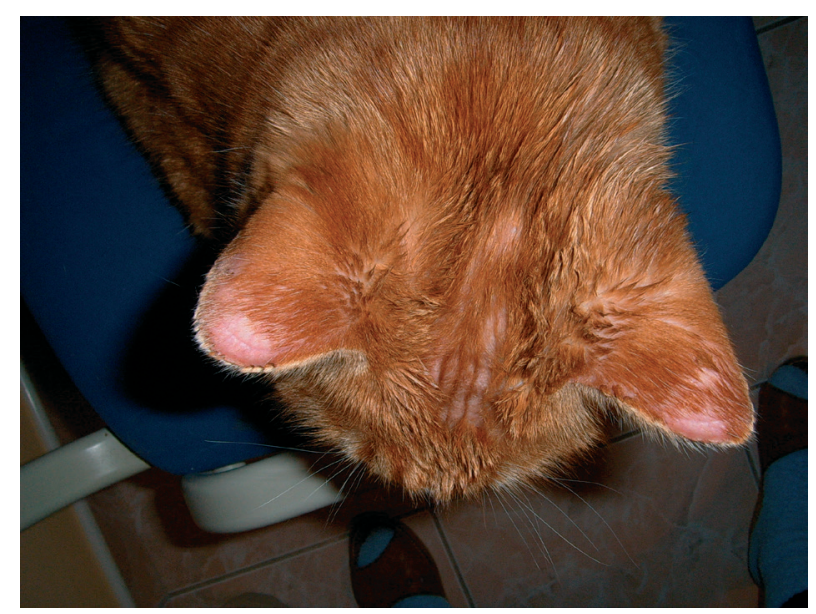

Figure 1. Typical ringworm lesions in a cat's ears due to Microsporum canis (Photo: W. Dardzińska)
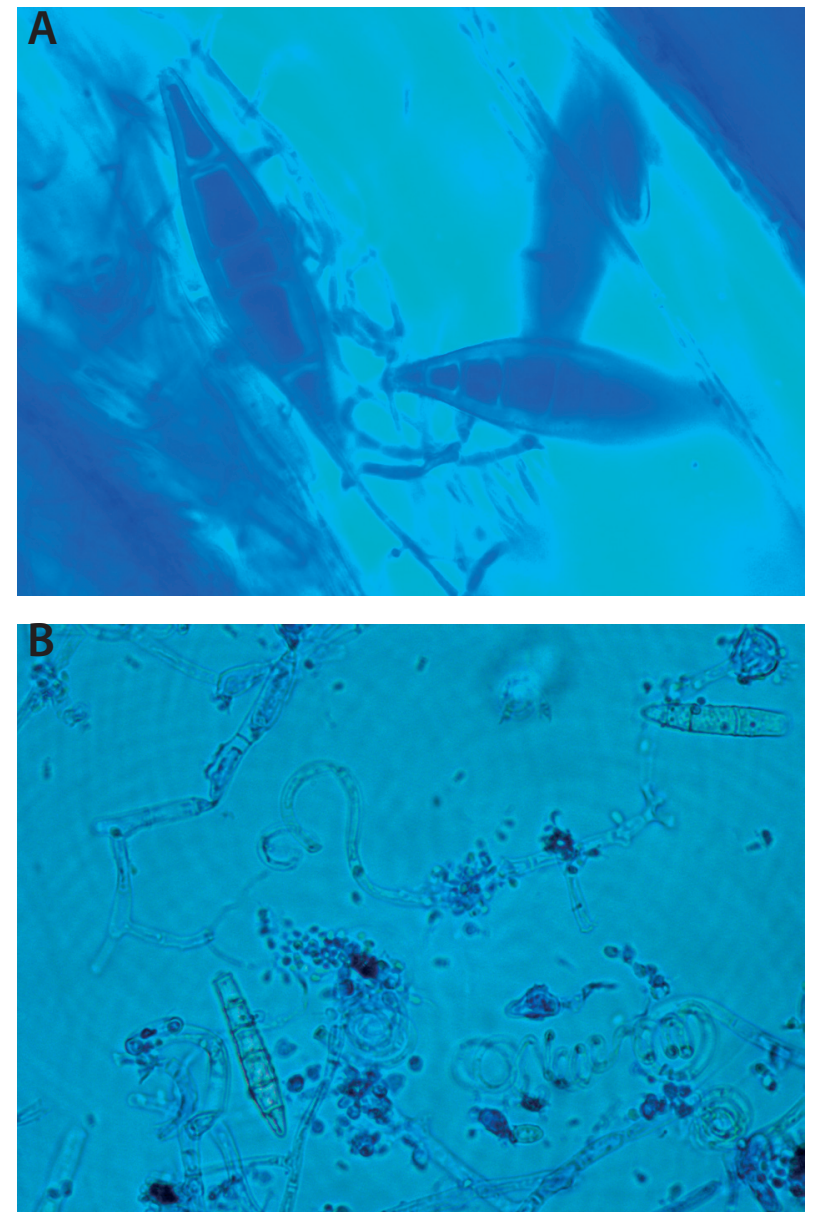

Figure 2. Photomicrograph of:

(A) macroconidia of Microsporum canis. Microconidia typically are absent. Macroconidia are fusoid, verrucose, and thick walled. They have a recurved apex and contain 5-15 cells.

(B) spiral hyphae of Trichophyton mentagrophytes. Microconidia are numerous, unicellular, round to pyriform and found in grape like clusters. Spiral hyphae are often present. Macroconidia are multiseptate, club-shaped (methylene blue, x1000) (Photo: I. Dąbrowska)

GCATCGTCTC3') and panDerm_rev (5'CTCGAGGTCAAAAGCACGCCAGAG3'), was used for PCR assay. Two different PCR mixtures were compared. The first was a commercial preparation (2xPCR Master Mix Plus High GC [A\&A Biotechnology]: Taq DNA polymerase $0.1 \mathrm{U} / \mu \mathrm{l}, \mathrm{MgCl} 24 \mathrm{mM}$, dNTPs (dATP, dCTP, dGTP, dTTP) $0.5 \mathrm{mM}$ of each $\mathrm{dNTP}$ ) and the second was a self-composed. Both contained $10 \mu \mathrm{l}$ of PCR Mix, 0.1 $\mu \mathrm{l}$ of each primer (panDerm_for and panDerm_rev) and $2 \mu \mathrm{l}$ of DNA in a total volume of $20 \mu \mathrm{l}$. PCR was performed in an Eppendorf Mastercycler thermocycler.

The time-temperature profile for PCR was; initial denaturation for $3 \mathrm{~min}$ at $95^{\circ} \mathrm{C}$ followed by $45 \mathrm{~s}$ at $94^{\circ} \mathrm{C}$, $45 \mathrm{~s}$ at $54^{\circ} \mathrm{C}$ or $56^{\circ} \mathrm{C}$ or $58^{\circ} \mathrm{C}$ and finally $45 \mathrm{~s}$ at $72^{\circ} \mathrm{C}$ for a total of 35 cycles. The presence of a specific PCR product of approximately $366 \mathrm{bp}$ was determined by electrophoresis on a $2 \%$ agarose gel containing ethidium bromide.

\section{RESULTS}

All of clinical specimens analysed by conventional 'gold standard' diagnostics (direct microscopy and culture) yielded positive results. The isolates obtained in culture, identified on the basis of their morphology in- 


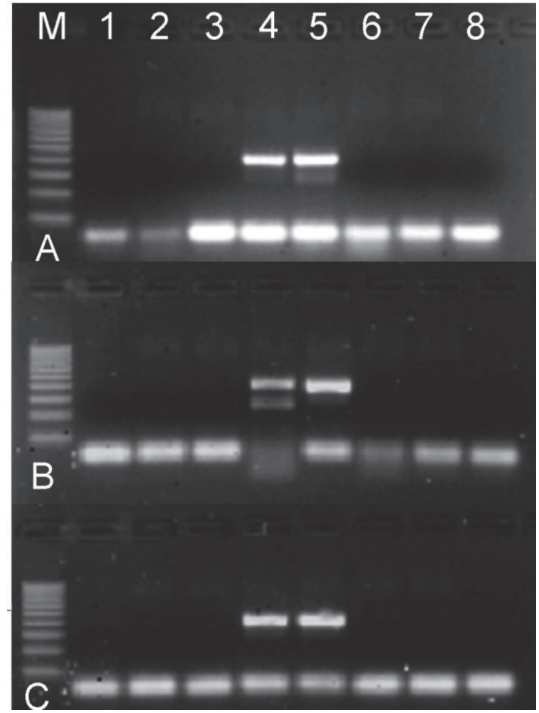

Figure 3. Electrophoretic patterns of PCR products with pan-dermatophyte primers and 2xPCR Master Mix Plus High GC (A\&A Biotechnology) at:

(A) $54^{\circ} \mathrm{C}$, (B) $56^{\circ} \mathrm{C}$ and $(C) 58^{\circ} \mathrm{C}$ annealing temperature. Lanes 1 and 8: negative control with water, lines 2 and 3: Microsporum canis, lines 4-7: Trichophyton mentagrophytes, line M: 100-1000 bp Ladder (A\&A Biotechnology).

Table 1. PCR results for the fifteen clinical specimens with growth

\begin{tabular}{|c|c|c|c|c|c|}
\hline $\begin{array}{l}\text { Number of } \\
\text { sample }\end{array}$ & $\begin{array}{l}\text { Species of } \\
\text { infected } \\
\text { animal }\end{array}$ & $\begin{array}{l}\text { Clinical } \\
\text { diagnosis }\end{array}$ & $\begin{array}{l}\text { Traditional method } \\
\text { identification }\end{array}$ & $\begin{array}{l}\text { PCR result (commercial mix; } \\
\text { annaeling temperature } 58^{\circ} \mathrm{C} \text { ) }\end{array}$ & $\begin{array}{l}\text { PCR result (homemade mix; } \\
\text { annaeling temperature } 58^{\circ} \mathrm{C} \text { ) }\end{array}$ \\
\hline 1. & dog & $\begin{array}{l}\text { skin lesions, } \\
\text { alopecia }\end{array}$ & $\begin{array}{l}\text { Trichophyton menta- } \\
\text { grophytes }\end{array}$ & lack of specific product & specific product, 366 bp \\
\hline 2. & cat & $\begin{array}{l}\text { skin lesions, } \\
\text { alopecia }\end{array}$ & Microsporum canis & lack of specific product & specific product, 366 bp \\
\hline 3. & dog & $\begin{array}{l}\text { skin lesions, } \\
\text { alopecia }\end{array}$ & $\begin{array}{l}\text { Trichophyton menta- } \\
\text { grophytes }\end{array}$ & specific product, 366 bp & specific product, 366 bp \\
\hline 4. & cat & $\begin{array}{l}\text { skin lesions, } \\
\text { alopecia }\end{array}$ & Microsporum canis & lack of specific product & specific product, $366 \mathrm{bp}$ \\
\hline 5. & dog & $\begin{array}{l}\text { skin lesions, } \\
\text { alopecia }\end{array}$ & $\begin{array}{l}\text { Trichophyton menta- } \\
\text { grophytes }\end{array}$ & lack of specific product & specific product, 366 bp \\
\hline 6. & cat & $\begin{array}{l}\text { skin lesions, } \\
\text { alopecia }\end{array}$ & Microsporum canis & lack of specific product & specific product, 366 bp \\
\hline 7. & dog & $\begin{array}{l}\text { skin lesions, } \\
\text { alopecia }\end{array}$ & $\begin{array}{l}\text { Trichophyton menta- } \\
\text { grophytes }\end{array}$ & lack of specific product & specific product, 366 bp \\
\hline 8. & cat & $\begin{array}{l}\text { skin lesions, } \\
\text { alopecia }\end{array}$ & Microsporum canis & lack of specific product & specific product, $366 \mathrm{bp}$ \\
\hline 9. & dog & $\begin{array}{l}\text { skin lesions, } \\
\text { alopecia }\end{array}$ & $\begin{array}{l}\text { Trichophyton menta- } \\
\text { grophytes }\end{array}$ & specific product, 366 bp & specific product, 366 bp \\
\hline 10. & dog & $\begin{array}{l}\text { skin lesions, } \\
\text { alopecia }\end{array}$ & $\begin{array}{l}\text { Trichophyton menta- } \\
\text { grophytes }\end{array}$ & lack of specific product & specific product, 366 bp \\
\hline 11. & cat & $\begin{array}{l}\text { skin lesions, } \\
\text { alopecia }\end{array}$ & Microsporum canis & lack of specific product & specific product, 366 bp \\
\hline 12. & cat & $\begin{array}{l}\text { skin lesions, } \\
\text { alopecia }\end{array}$ & Microsporum canis & lack of specific product & specific product, $366 \mathrm{bp}$ \\
\hline 13. & dog & $\begin{array}{l}\text { skin lesions, } \\
\text { alopecia }\end{array}$ & $\begin{array}{l}\text { Trichophyton menta- } \\
\text { grophytes }\end{array}$ & lack of specific product & specific product, 366 bp \\
\hline 14. & cat & $\begin{array}{l}\text { skin lesions, } \\
\text { alopecia }\end{array}$ & Microsporum canis & lack of specific product & specific product, 366 bp \\
\hline 15. & cat & $\begin{array}{l}\text { skin lesions, } \\
\text { alopecia }\end{array}$ & Microsporum canis & lack of specific product & specific product, 366 bp \\
\hline
\end{tabular}

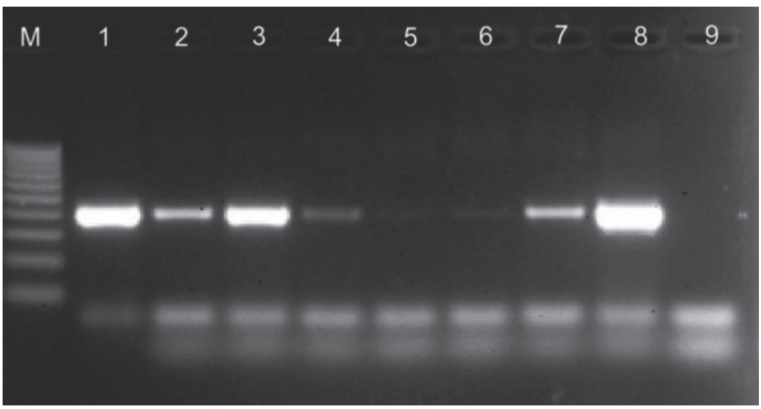

Figure 4. Electrophoretic patterns of PCR with pandermatophyte primers and at $58^{\circ} \mathrm{C}$ annealing temperature and homemade PCR mix.

Lanes 1 and 8: Trichophyton mentagrophytes, lines 2-7: Microsporum canis, line 9 negative control with water, line M: 100-1000 bp Ladder (A\&A Biotechnology).

cluded seven representatives of the Trichophyton mentagophytes complex strains and eight Microsporum canis. PCR assay confirmed correct identification of strains as dermatophytes (Table 1).

Using the pan-dermatophyte PCR primers and cycling conditions described by Bsrillowska-Dabrowska and coworkers (2007), both specific and unspecific products were obtained at annealing temperature under $58^{\circ} \mathrm{C}$ in the presence of commercial PCR mix (Fig. 3A, B). A 
specific product (approx. $366 \mathrm{bp}$ ) was visible only at the annealing temperature of $58^{\circ} \mathrm{C}$ (Fig. 3C). Commercial PCR mix yielded a specific product only when T. mentagrophytes DNA was used in the reaction, while the selfcomposed PCR mix (with lower concentration of $\mathrm{KCl}$ ) produced specific products from both $T$. mentagrophytes and $M$. canis (Fig. 4). No contamination of negative control samples (water) was observed under the experimental conditions described here.

Although the one-step procedure described here cannot distinguish individual fungal species, the results indicate that the PCR approach may allow detection of dermatophyte specific DNA from $M$. canis and T. mentagrophytes.

\section{DISCUSSION}

By far the most frequently diagnostic techniques used for confirmation of dermatophyte infection are direct microscopy and cultivation on Sabouraud's dextrose agar (Tchernev et al., 2013). So far this procedure has permitted identification of the etiological agent thus facilitating the selection of appropriate treatment. However, traditional methods have a diagnostic sensitivity of $50-70 \%$, while $30-50 \%$ of fungal agents cannot be identified by conventional means (Weinberg et al., 2003). In laboratory practice there are cases when precise identification of dermatophyte species is impossible due to lack of sporulation. A solution to this problem could be isolation of DNA with subsequent sequence determination followed by alignment with fungal databases. Unfortunately, such an approach is time consuming and rather too expensive for routine work. The method proposed here shows good detection and agreement with the traditional method.

Although the use of self-composed PCR mix allowed a 100\% detection of dermatophyte DNA, nonetheless, there is a need to optimize the protocol. The necessity to optimize arises from using different reagents than those used in the Brillowska-Dabrowska approach (2007). Moreover, it should be emphasized that the gold standard methods permit correct identification only if performed by a qualified mycologist with a good knowledge of dermatophyte morphological features such as micro- and macroconidia, the presence of chlamydospores etc. In this study, detection was possible in less than five hours (not including the time of culture) and results were more objective and independent of the investigator. Mycological knowledge is not required for implementation and interpretation of the results. In addition, the analysis requires a small amount of sample as would be in clinical specimens.

Only a limited number of diagnostic laboratories use modern molecular techniques such as PCR in routine diagnostics due to lack of a universally accepted diagnostic algorithm (Tchernev et al., 2013). However, the method of fungal DNA extraction proposed by BrillowskaDabrowska and coworkers (2007) brings hope that simple, fast, and low-cost diagnoses of dermatophytosis of animals may become available as a standard in routine veterinary laboratory diagnosis.

This is the first step of research with the object of designing an optimal, simple and fast method of detection and identification of dermatophytes on the level of species directly in clinical veterinary samples.

\section{REFERENCES}

Arabatzis M, Xylouri E, Frangiadaki I, Tzimogianni A, Milioni A, Arsenis G, Velegraki A (2006) Rapid detection of Arthroderma vanbreuseghemii in rabbit skin specimens by PCR-RFLP. Vet Derm 17: 322-326.

Ameen M. (2010) Epidemiology of superficial fungal infections. Clin Dermatol 28: 197-201.

Brillowska-Dąbrowska A, Saunte DM, Arenderup MC (2007) Fivehour diagnosis of dermatophyte nail infections with specific detection of Trichopbyton rubrum. J Clin Microbiol 45: 1200-1204.

Chermette R, Ferreiro L, Guillot J (2008) Dermatophytoses in animals. Mycopathologia 166: 385-405.

Dworecka-Kaszak B. (2011) DNA-based detection of dermatophytes infections. Diagmol. SGGW, 40-44.

Faggi E, Pini G, Campisi E (2002) PCR fingerprinting for identification of common species of dermatophytes. I Clin Microbiol 40: 4804-4805.

Graser Y, Kuijpers AF, El Fari M, Presber W, De Hoog GS (2000) Molecular and conventional taxonomy of the Microsporum canis complex. MedMycol 38: 143-53.

Hryncewicz A, Jagielski T, Dobrowolska A, Szepietowski JC, Baran E (2011) Identification and differentiation of Trichophyton rubrum clinical isolates using PCR-RFLP and RAPD methods. Eur J Clin Microbiol Infect Dis 30: 727-731.

Jaya G, Ragini T, Atul G, Pradyot P, Anil KG, Gopal N (2009) Rapid detection of dermatophytes from skin and hair. BMC Res Notes 2: 60.

Levitt J O. Levitt B H, Akhavan A, Yanofsky H (2010) The sensitivity and specificity of potassium hydroxide smear and fungal culture relative to clinical assessment in the evolution of tinea pedis: a pooled analysis. Dermatol Res Pract 2010: 1-8.

Liu D, Coloe S, Baird R, Pedersen J (2000) Application of PCR to the identification of dermatophyte fungi. J Med Microbiol 49: 493-497.

Mahoney J M, Bennet J, Olsen B (2003) The diagnosis of onychomycosis. Dermatol Clin 21: 463-467.

Putignani L, D’ Arezzo S, Paglia MG, Visca P (2010) DNA-based detection of human pathogenic fungi: dermatophytes, opportunists, and causative agents of deep mycoses. In Molecular identification of Fungi. Gherbawy Y, Voigt K, eds, pp 357-415. Springer, Heidelberg, Dordrecht, London, New York.

Tchernev G, Penev PK, Nenoff P, Zisova LG, Cardoso JC, Taneva T, Ginter-Hanselmayer G, Ananiev J, Gulubova M, Hristova R, Nocheva D, Guarneri C, Martino G, Kanazawa N (2013) Onychomycosis: modern diagnostic and treatment approaches. Wien Med Wochenschr 163: 1-12.

Verrier J, Pronina M, Peter C, Bontems O, Fratti M, Salamin K, Schurch S, Gindro K, Wolfender JL, Harshman K, Monod M (2012) Identification of infectious agents in onychomycoses by PCR-terminal restriction fragment length polymorphism. J Clin Microbiol 50: 553-561.

Verrier J, Krahenbuhl L, Bontems O, Fratti M, Salamin K, Monod M (2013) Dermatophyte identification in skin and hair samples using a simple and reliable nested-PCR assay. Brit J Dermatol 168: 295-301.

Weinberg JM, Koestenblatt EK, Tutrone WD, Tishler HR, Najarian $\mathrm{L}$ (2003) Comparison of diagnostic methods in the evaluation of onychomycosis. J Am Acad Dermatol 49: 193-197.

Weitzman I, Summerbell RC (1995) The dermatophytes. Clin MicrobialRev 8: 240-259.

Wisselink GJ, van Zanten E, Kooistra-Smid AMD (2011) Trapped in keratin; a comparison of dermatophyte detection in nail, skin and hair samples directly from clinical samples using culture and realtime PCR. J Microbiol Meth 85: 62-66. 